\title{
Wine tourism product clubs as a way to increase wine added value: the case of Spain
}

\author{
This article was published in the following Dove Press journal: \\ International Journal of Wine Research \\ 9 June 2010 \\ Number of times this article has been viewed
}

\section{Francisco José Del Campo Gomis \\ David López Lluch José Miguel Sales Civera Asunción M Agulló Torres Margarita Brugarolas Mollá-Bauzá África Martínez Poveda Fermín Camacho de los Ríos \\ Antonio Miguel Nogués Pedregal}

Departament of Agrienvironmental Economics, Universidad Miguel Hernández, Campus Universitario de Orihuela-Desamparados, Orihuela (Alicante), Spain
Correspondence: Francisco José Del Campo Gomis

Universidad Miguel Hernández, Departament of Agrienvironmental Economics, Campus Universitario de Orihuela-Desamparados, 03312 Orihuela (Alicante), Spain

Tel +34966749624

Email f.j.campo@umh.es

\begin{abstract}
The objective of this paper is to analyze how the wine tourism product clubs work in Spain and their importance for Spanish wine tourism. A tourism product club is a product development partnership established and led by the tourism industry stakeholders including small- and/or medium-sized companies. The group pools its resources to develop new marketready products or to increase the value of existing ones. Lodging companies, tour operators, administrators of tourism facilities, tourist associations, government, other companies of the sector and, even, nontourist companies can participate as members of a tourism product club. Following this model, wine tourism can contribute to create a wine tourism product club. In Spain the international promotion of tourist products is carried out through the Turespaña website. The wine tourism product club, The Wine Routes of Spain, is one of the wine tourism product clubs developed by the Spanish government. It is an ambitious project that began in 2001. Nevertheless, other Spanish regions have created more wine tourism product clubs in order to develop their own wine tourism industry such as "Divinum vitae - Where the pleasues are born" created in Castilla-La Mancha in 2006.
\end{abstract}

Keywords: wine, tourism, product club, Spain

\section{What is a tourism product club?}

A tourism product club is a group of companies that have agreed to work together to develop new tourism products or increase the value of existing products and collectively review the existing problems that hinder profitable development of tourism. ${ }^{1}$ Tourism product clubs share an interest in a sector of the tourism industry and aims to increase the variety and quality of products available (packages, events, activities, experiences) and/or develop new products for a specific market segment. The group is committed to conducting a program of development of tourism products for a period of at least three to five years.

The three main lines of development of the tourism product club are:

1. Communication to the tourism enterprise.

2. Education for the tourism industry.

3. Research of segment needs.

Tourism product clubs usually resolve problems that represent barriers to productivity and business efficiency (usually small and medium enterprises) around tourism. Specific activities to be carried out by a tourism product club are:

1. Businessmen's association in joint projects.

2. Research of specific markets needs.

3. Identification of potential markets and segments. 
4. Evaluation of successful initiatives in other places (benchmarking).

5. Implementation of a development strategy and marketing of the activity concerned.

6. Creation of new packages.

7. Seminars.

8. Production of newsletters and other communications (business to business: B2B).

At the end of the development cycle of the tourism product, the company has the chance of launching new or improved tourism products ready to market. Therefore, the main generic strengths of the concept of tourism product clubs are:

1. Their capacity to group shareholders around activities and strategies that they could not solve alone.

2. Conducting market research in a co-operative way.

3. Shared dissemination of information and knowledge.

4. The ability to develop and put in the market innovative and/or alternative products that may attract a diverse audience of travelers.

Members are often existing accommodation establishments, tour operators, managers of tourist attractions, tourist associations, municipal, regional and state governments, other tourism companies, and even companies outside the tourism sector.

The name of the tourism product club is given to business groups engaged in a specific business niche, topic or product while receiving official support to develop it and can offer advice to other groups. Subsequently, clubs operate as development offices with resources from the industry itself once government support is removed. Therefore, the condition of the tourism product club should be, according to the perspective of the public administration, a temporary status maintained while the sector is able to develop its own market intelligence activities and planning products.

\section{What should not be a tourism product club?}

In the first instance, a tourism product club can be confused with other administrative figures of the sector but it has different objectives in comparison to traditional institutions, so it is important to clarify what should not be a product club: ${ }^{1}$

a) A promotion fund.

They should not have funds for the promotion of destinations and activities (advertising, brochures, media, web pages, etc.). However members may, of course, perform their own marketing activities.

b) An association.
An association should not seek to duplicate the functions of the tourism offices that are in charge of management, promotion, and information to visitors.

c) A development fund.

The purchase of real estate, infrastructure construction, training or financing companies should not be supported through the club.

Moreover, some related ideas are considered tourism product clubs, although they are not, for example, clusters, advisory councils, and committees.

The tourism product club is a tool to build business clusters in the country and it serves to raise the level of competition for the wine destinations, even though the club's reach is broader.

The fundamental difference between a tourism product club and the advisory councils and committees established at various levels to address issues relating to a product in particular is in the level of commitment and type of participation of each member. The level of commitment of members of a tourism product club is much narrower than that of councils and advisory committees and, therefore, its range and possibilities of performance are greater.

\section{Advantanges and benefits of a tourism product club}

Developing tourism product clubs has the immediate advantage of strengthening dialogue with the large number of companies who work in a market segment or specific tourism activity, regardless of the importance of the location or destination.

A tourism product club generates the following generic opportunities or advantages. ${ }^{1}$

1. Formalization of collaborative actions among stakeholders in the development of the sector, topic or niche of the tourism market.

2. Establishment of commercial synergies among participants.

3. Potential increase of the market of a topic or niche.

4. Increase of efficiency in the tourism operations of a specific sector of the tourism market.

5. Creation of spaces for dialogue between the public organization and private initiative.

On the other hand, analyzing and addressing the specific needs of development of each activity through the tourism product clubs helps address problems that impede or constrain the development of each segment, enhances the capabilities of its members (synergies), and promotes the country's competitiveness in key and emblematic segments of world tourism. 
Tourism product clubs do not only benefit the producers. The main advantage of clubs is for customers and communities to share these advantages due to the profit generated by service providers. The generic benefits produced by a tourism product club can be divided into three main groups: economic, physical, and emotional (Table 1).

By encouraging cooperation among different stakeholders in tourism industries, tourism product clubs continue the relationships between companies and organizations that have traditionally acted independently of government policy and are otherwise isolated in an industry whose success depends precisely on integration. The key to success lies in creating synergies that enhance individual capabilities and generate a higher added value than the one each business can generate on their own. In this, the creation of a climate of trust that allows the interaction is a condition sine qua non in order to work properly.

\section{Wine tourism product clubs in Spain}

Wine tourism is emerging as an alternative holiday and economic development industry in Spain. The growing eagerness to experience the world of wine culture for leisure and entertainment, has increased the numbers of 21 st-century travelers taking up the holiday and leisure that wine tourism offers. At the same time, the development of wine culture and the recognition of the economic importance of the production of wine is a phenomenon that has led to an increase in the quantity and variety of vineyards and production areas around the world.

Wine tourism is a tourism industry in which several elements involved in the process of wine (wineries, vineyards, and their environment) are central to the vacation experience and the industry enhances the added value generated by the wine through the wine tourism product clubs.
In this section, two examples of wine tourism product clubs that currently operate in Spain will be shown; the first one at a national level and the second one at a regional level.

\section{Wine tourism product club: The Wine Routes of Spain}

The promotion of The Wine Routes of Spain by Turespaña follows the national program of objectives for international wine promotion set out in 2007, which was to "facilitate marketing of tourism products according to the current needs and opportunities in international markets for each segment. Support the creation of product clubs, and using marketing techniques in each case to make the use of distribution channels more effective."

Turespaña is an agency of the Spanish State Administration which is responsible for the international promotion of Spain as a tourist destination and has a network of 31 Spanish Tourist Offices worldwide, including in America, Europe, and Asia. Its official website of tourism is translated into four languages (Spanish, English, French, and German) and versions in Italian, Russian, Japanese, and Chinese have been customized.

New tourism products have been developed by supporting the following product clubs: marinas, wine routes, spas, incentives, congresses, idiomatic tourism, and camping.

Among the tourism product clubs sponsored by the Government of Spain, the wine tourism product club, The Wine Routes of Spain was promoted by the Spanish Association of Wine-producing Cities (Acevin) and the General Secretariat of Tourism of the Spanish Government in collaboration with Turespaña and Ministry of the Environment and Rural and Marine Affairs.

The Spanish Association of Wine-producing Cities (Acevin) brings together 43 municipalities with 22 wine appellations of origin. From the outset, this group encouraged

Table I Generic benefits produced by a tourism product club'

\begin{tabular}{|c|c|c|c|}
\hline Type of benefit & Members & Tourists & Community \\
\hline Economic & $\begin{array}{l}\text { - Greater market opportunities } \\
\text { and income at a lower cost }\end{array}$ & $\begin{array}{l}\text { - Greater alternatives of consump- } \\
\text { tion }\end{array}$ & - Greater employment opportunities \\
\hline Physical & $\begin{array}{l}\text { - Increased market penetration } \\
\text { with less individual effort } \\
\text { - Increased forecasting of } \\
\text { seasonal demand }\end{array}$ & $\begin{array}{l}\text { - Greater diversity of supply at point } \\
\text { of sale }\end{array}$ & - Increased forecasting demand \\
\hline Emotional & $\begin{array}{l}\text { - Increased certainty for market } \\
\text { shares } \\
\text { - Increased competitiveness } \\
\text { - Increased credibility } \\
\text { - Improved business image }\end{array}$ & $\begin{array}{l}\text { - Increased certainty of purchase } \\
\text { - Increased confidence in the quality } \\
\text { of service }\end{array}$ & $\begin{array}{l}\text { - Best image of the destination service } \\
\text { - Increased confidence in own ability }\end{array}$ \\
\hline
\end{tabular}


the promotion of culture and wine tourism as a strategy for local development and wealth and employment creation.

The Wine Routes of Spain is an ambitious project that began in 2001 and its fourth phase has established a consolidation of wine tourism in the most important wine regions of Spain. The Wine Routes of Spain integrates resources and services of interest in a particular area of Spain where the wine territory is rich.

Among the main projects undertaken are:

1. Development and regulation of the wine routes in Spain.

2. Implementation and development of a training course for technicians of local councils in managing wine routes.

3. Development of a methodological guide for the creation of wine routes.

The aim is to build a product based on the quality and identity of the target, which maximizes joint marketing, and manages the level of demand response and socioeconomic development of the territory. Therefore, The Wine Routes of Spain is a tourism product whose primary focus is viniculture. Visitors can find wineries, stroll through vineyards, take part in tastings, lunch while wine tasting at wineries, and observe agricultural activities such as pruning and harvesting, all without neglecting the enjoyment of the cultural and gastronomic heritage of the different areas.

The concept of the wine route is to create business opportunities in certain rural destinations for the cultural and rural tourism product, based on wine, culinary, and cultural experiences, including a wide range of accommodation and wine-related services (such as wine shops, wine bars, and wine museums) as well as a wide range of complementary entertainment activities such as golf, horse-riding, commercial offerings, restaurants, and nightlife.

This broad range of wine tourism activities is targeted at clients who seek in general to visit wineries, villages, monuments, museums and exhibitions in addition to buying, tasting wines and enjoying the cuisine and cultural experiences Spain has to offer; that is, a tourist who needs several integrated services, which must meet the highest standards of quality.

Wine tourism is driving the development of rural areas, generating jobs and wealth, increasing the sale of wine, improving the environment and infrastructure, and also developing tourist activity all year round.

This wine product club offers an active stay in rural surroundings where the customer enjoys comfortable accommodation, experiences wine culture and tastes wine accompanied by typical food of the region, in addition to a number of complementary actitivies.
The objectives of creating a network of Spanish wine routes are:

1. To coordinate the various wine routes.

2. To establish a coordinated procedure for creating them.

3. To create a tool for tourism development in wide rural areas economically linked to wine production.

4. To establish a mechanism for harmonization and coordination within the wine industry.

5. To create a quality product to serve as a differentiating and satisfying element of the cultural experience Spain.

Belonging to the Spanish wine routes offers a guaranteed quality of service and equipment. This has been defined by a quality plan that sets standards, with the dual aim of shaping the prerequisites that all members must accomplish regarding the facilities and the offered service, and establishing criteria for classification of new products which form part of the wine based on the defined standards. In fact, from a formal point of view, a wine route must comply with quality standards and self-regulatory rules that both Acevin and the General Secretariat of Tourism of the Spanish Government have set in the manual of the wine tourism product club, The Wine Routes of Spain. This manual defines the requirements of management systems, signage, promotion and marketing, and the specific types of buildings that form part of the route: wineries, restaurants, shops, service companies, and so on.

The basic principles for wine route development and the definition of the quality system for partnerships are:

1. A self-regulatory system so that city councils, regulatory boards, businessmen, and key stakeholders have a primary role in shaping and launching the product.

2. The orientation of the business. Belonging to a wine route, the business must endeavor to obtain better results.

A wine route should have the following resources:

1. Fifteen percent of wineries in the area that meet all accreditation requirements such as a representative volume of supply: at least five catering establishments, three accommodation establishments, and two wine shops.

2. Tourism management and business associations of hotels and restaurants should ideally be represented.

At this time, the Spanish wine routes total 19, of which 13 are fully certified: Wine Route of Bullas (Murcia), Jumilla (Murcia), La Mancha, Wine and Brandy Route of Marco de Jerez, Wine Route of Montilla-Moriles, Navarra, Rías Baixas, Rioja Alavesa, Somontano (Aragon), Tacoronte-Acentejo (Canary Islands), and Wine and Cava Route of Penedès (Catalonia). Six wine routes are currently going through the certification process. Wine Route of Ribera del Duero, Rioja Condado de Huelva, Ribeiro (Galicia), Utiel-Requena (Valen- 
cian Community), Acoden-Daute-Isora (Canary Islands), Ribera del Guadiana (Extremadura) and Alicante (Valencian Community) (Figure 1).

Once established, the tourist product The Wine Routes of Spain was incorporated into the Turespaña website, which offers access to all channels of promotion, distribution, and marketing of this state body (international fairs, inclusion in http://www.spain.info/, promotion through the Spanish Office of Tourism, and so on).

Development and tourist promotion of the product The Wine Routes of Spain was supported from 2006 to 2009 by the General Secretariat of Tourism and the Ministry of the Environment and Rural and Marine Affairs of the Government of Spain with a combined global budget of $€ 1,200,000$.

Nowadays, The Wine Routes of Spain is beginning a fourth phase, which is supposed to be a continuation of the marketing plan (a new website of the wine routes of Spain http://www. wineroutesofspain.com/ and quarterly newsletters). Similarly, another big project is the creation of the Observatory of Wine
Routes in Spain, as well as for training and technical assistance for all routes that completely certified or waiting to achieve certification.

In 2008, the number of visitors to wineries associated with wine routes in Spain amounted to $1,198,199$ (Figure 2). The route with 14 of the most visitors was the Wine and Cava Route of Penedès (Oenotourism Penedès) with 457,896 visitors. The second highest number of visitors was to the Wine and Brandy Route of Marco de Jerez (434,161 visitors). We should comment in this regard that both these oenotourism areas have some of the most visited wineries in the world such as Codorniu and Freixenet in Penedès, or Gonzalez Byass Tio Pepe at Marco de Jerez, which have over 100,000 annual visitors. Other routes that have obtained relevant figures are Rioja Alavesa (80,688 visitors), Utiel-Requena (47,496 visitors), and Somontano (46,099 visitors). These totals do not include statistical data from the associated wineries of the Wine Route of Rioja Alta, which will undoubtedly receive outstanding numbers of visitors.

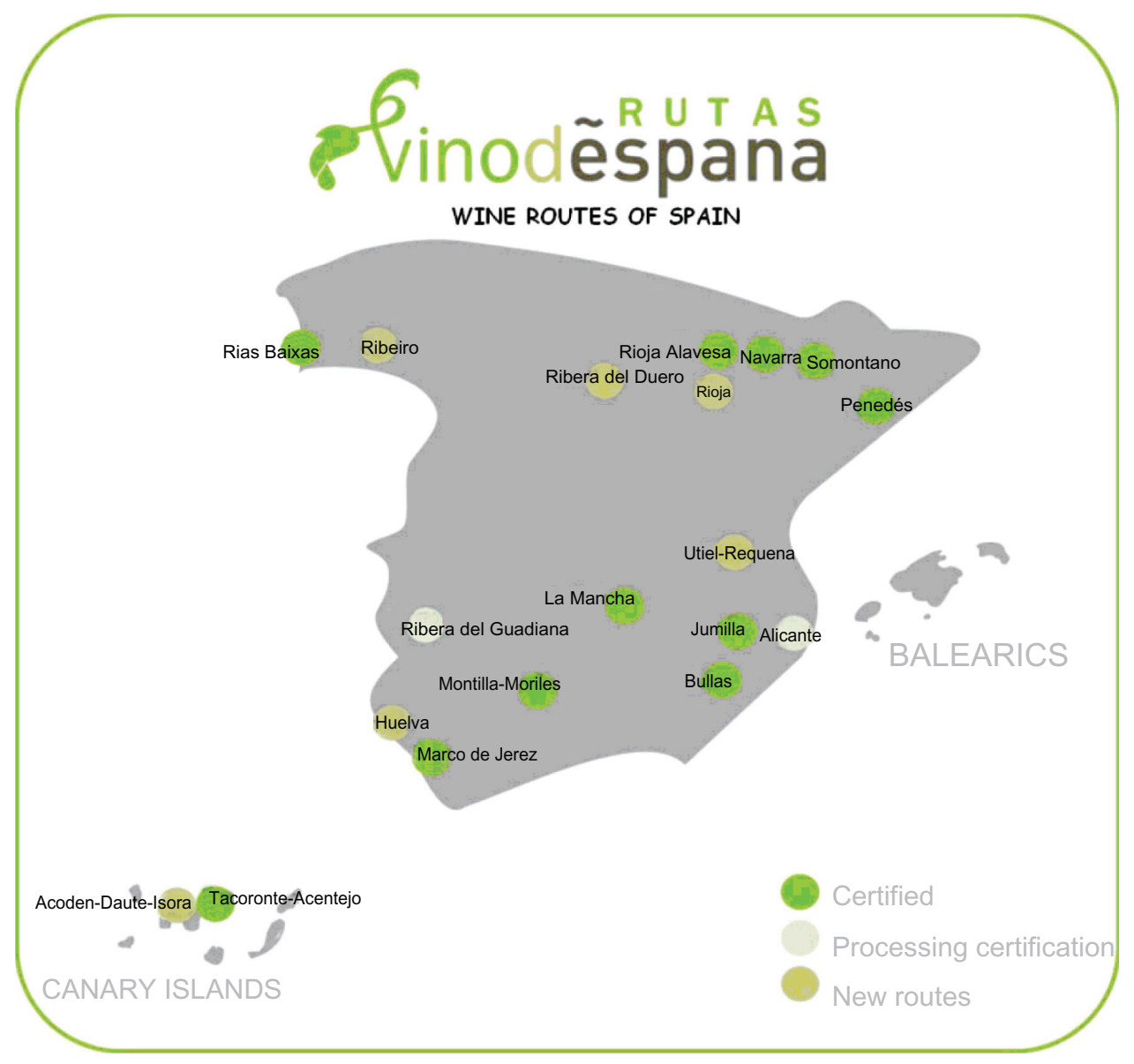

Figure I Wine tourism product club:The Wine Routes of Spain. ${ }^{4}$ 


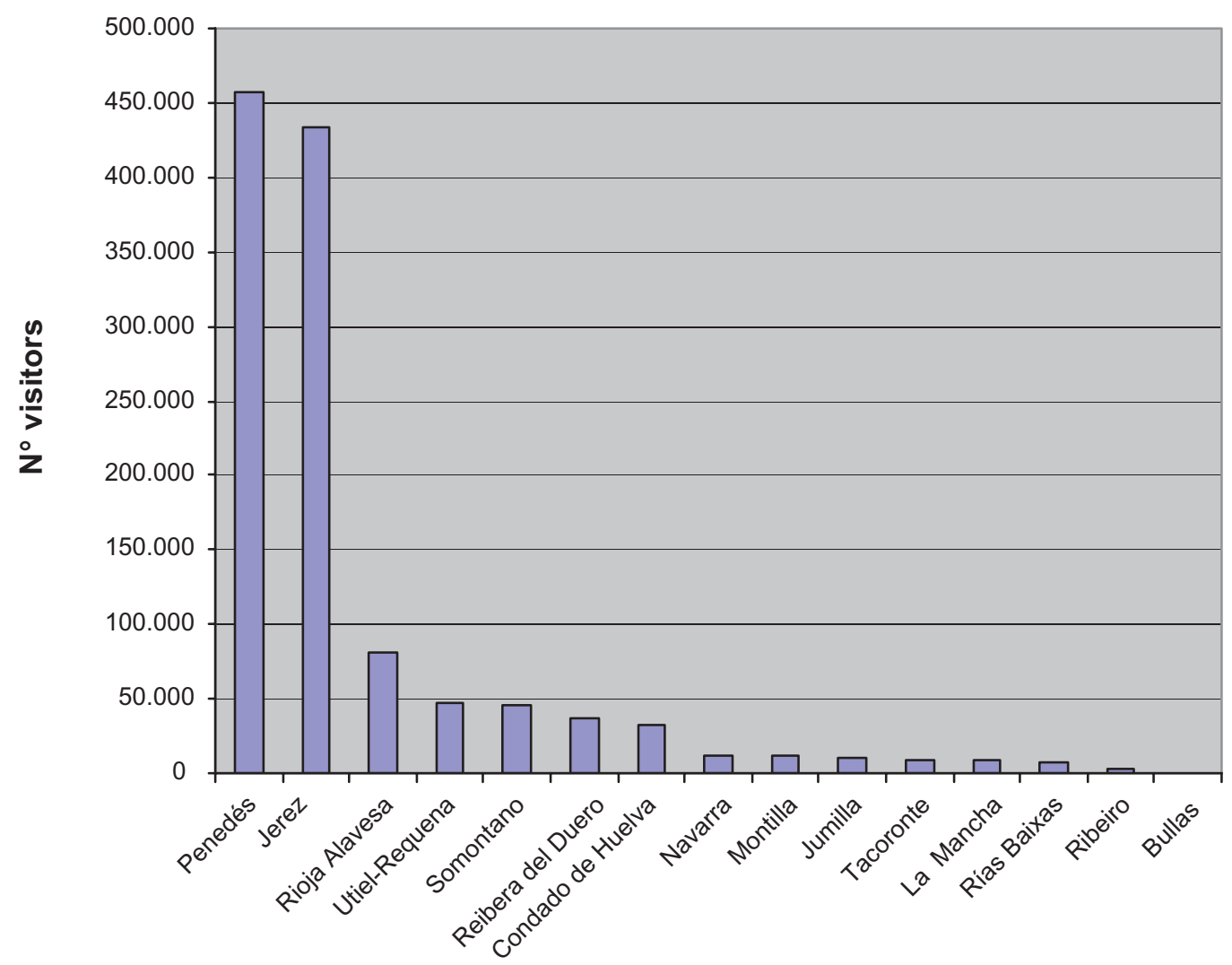

Figure 2 Number of visitors of each wine route in Spain. ${ }^{4}$

If we analyze visitor arrivals by month (Figure 3), we see that May $(143,228)$, October $(139,732)$, and September $(132,900)$ are the most successful due to the effects of pre- and post-harvest. Interestingly the peak months for tourists to Spain are July and August, when the numbers of visitors drop below 100,000 visitors each month. This can be attributed to several causes, such as the high temperatures to be found in some of wine producing areas.

In view of these results, this wine tourism product club generates a type of wine tourism with great staying power all year round, which divides the demand over several months of the year and avoids congestion and supports economic activity more consistently than the tourism products of sunshine and beaches.

\section{Wine tourism product club: "Divinum vitae - Where pleasures are born" of Castilla-La Mancha}

To enhance wine tourism in the Spanish region of Castilla-La Mancha, the Tourism Promotion Institute for the region was created by the Wine Tourism Association of Castilla-La Mancha. In 2006, the wine tourism product club for Castilla-
La Mancha was launched under the brand Divinum Vitae - Where pleasures are born. ${ }^{3}$

The Wine Tourism Association of Castilla-La Mancha is an association of 35 wineries that aim to promote wine-related tourism in this region (Figure 2). In addition, there are some recommended lodging establishments (30) and restaurants (39) which are not ex officio members of the Association, but by a small membership fee they benefit from their activities and participate, albeit indirectly, in the wine tourism product club. The Association has designed 10 wine routes that offer a variety of activities based around the winery: wine tasting, visiting vineyards, restaurants, accommodation, wine shops, tasting rooms, tasting course, using meeting rooms for conferences, and events and activities for children.

This wine tourism product club was formally constituted by an agreement between the Institute for Tourism Promotion and Wine Tourism Association of Castilla-La Mancha. In 2008, the wine tourism product club had total budget of $€ 250,000$, derived from the Institute of Tourism Promotion $(80 \%$; $€ 200,000)$ and the Association $(20 \%$; $€ 50.000)$. 


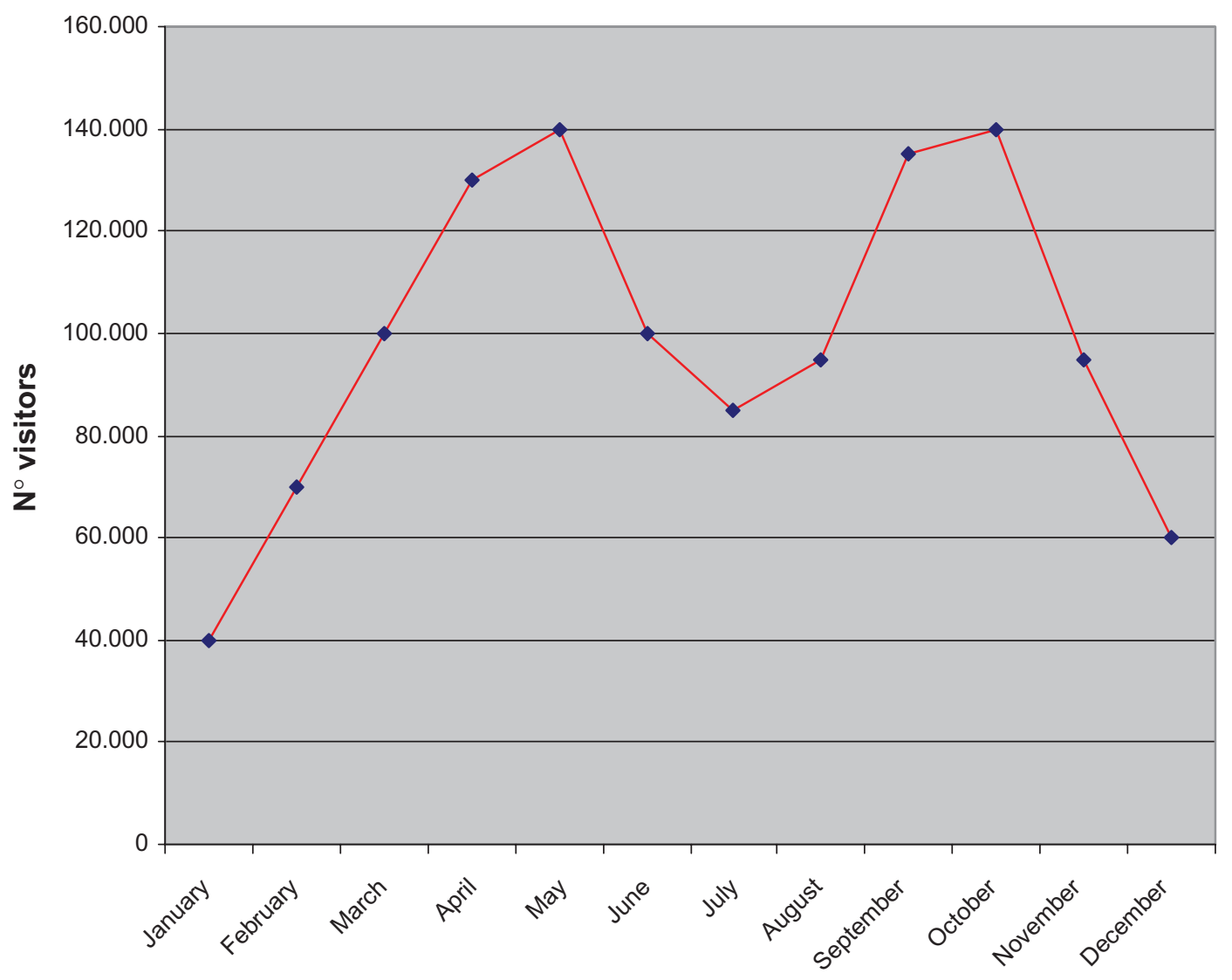

Figure 3 Number of visitors to wine routes in Spain by months. ${ }^{4}$

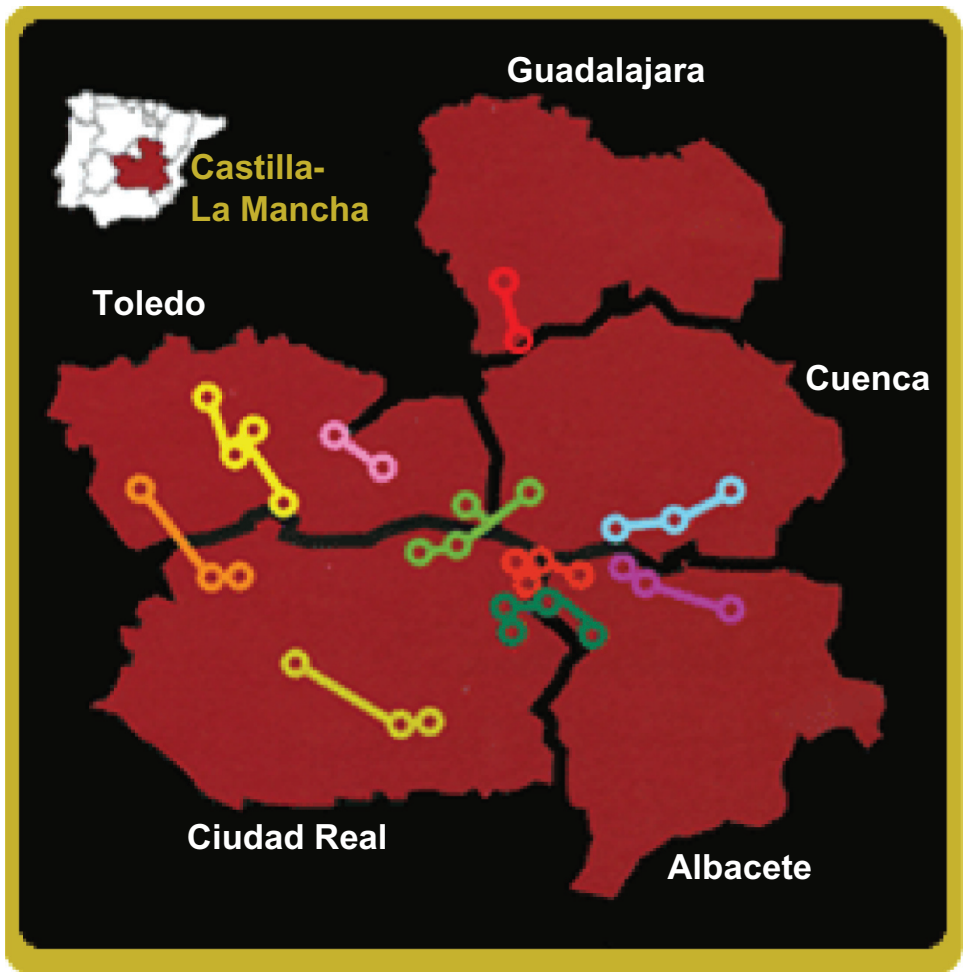

Figure 4 Wine tourism product club Divinum Vitae (Castilla-La Mancha). ${ }^{3}$ 


\section{Conclusions}

A wine tourism product club is a group of companies that agree to work together to develop new tourism products or to increase the value of existing products in relation to the wine market segment or wine tourist activity.

In Spain, wine tourism product clubs have been launched to enhance the value of the wine tourism industry by generating all-year round tourism that spreads tourism demand over several months of the year. This avoids congestion and supports consistent economic activity for the wine tourism product clubs The Wine Routes of Spain at the national level and the wine tourism product club Divinum Vitae - Where pleasures are born in the region of Castilla-La Mancha.

\section{Disclosures}

The authors report no conflicts of interest in this work.

\section{References}

1. Secretaría de Estado para el Turismo de México (SECTUR). Cómo crear clubs de producto. 2006. http://codeturnl.ensi.com.mx/. Accessed Nov 1, 2009.

2. Instituto De Turismo De España - Turespaña. http://www.tourspain. es/Accessed Nov 1, 2009.

3. Divinum Vitae. Wine tourism in Castilla-La Mancha. 2008. http://www. enoturismocastillalamancha.com/Accessed Nov 1, 2009.

4. Rutas del Vino de España. http://www.wineroutesofspain.com/. Accessed Nov 1, 2009.

\section{Publish your work in this journal}

The International Journal of Wine Research is an international, peer-reviewed open-access, online journal focusing on all scientific aspects of wine, including: vine growing; wine elaboration; human interaction with wine; and health aspects of wine. The journal provides an open access platform for the reporting of evidence based studies on these topics. The manuscript management system is completely online and includes a very quick and fair peer-review system, which is all easy to use. Visit http://www.dovepress.com/testimonials.php to read real quotes from some of our published authors. 